\title{
Rudolf Virchow
}

\author{
Dr. Siddharth P. Dubhashi ${ }^{1}$, Dr. Ratnesh Jenaw ${ }^{2}$ \\ ${ }^{1}$ Director (Academics And Student Affairs), Professor And Head Of Unit ${ }^{1}$, PG Student ${ }^{2}$ \\ ${ }^{2}$ Department Of Surgery, Mahatma Gandhi Medical College And Hospital, Mahatma Gandhi University Of \\ Medical Sciences And Technology, Jaipur
}

\begin{abstract}
Rudolf Carl Virchow (1821-1902), was a German doctor, pathologist, social eformer,anthropologist, writer, editor and politician. He is known as "the Father of Modern Pathology" and is the "Founder of Social Medicine". He founded the journal "Virchows Archive ". He adored the first chair of pathological Anatomy at the University of Wurzburg in 1849. He was awarded the Copley Medal of the British Royal Society. He has made significant contributions in the field of Medicine and Surgery.
\end{abstract}

Keywords: contributions, pathology, social medicine, Virchow

\section{INTRODUCTION}

Rudolf Carl Virchow [1], born on $13^{\text {th }}$ October 1821 at Schivelbein, Prussia (now Swidwin, Poland),was a German doctor, pathologist, social reformer, anthropologist, writer, editor and politician. He is known as "the Father of Modern Pathology" and is the "Founder of Social Medicine"[1] . He graduated from the Friedrich Wilhelm Institute of the University of Berlin in 1843, where he studied under the tutelage of Johannes Muller. He was an intern at the Charite Hospital, where he learned microscopy for his interest in pathology . In1847, he along with his colleague Benno Reinhardt , founded the journal " Archives for pathological Anatomy and Physiology and for clinical Medicine", later known as Virchow's Archive[2] . In 1848, the Prussian government appointed him to investigate an outbreak of typhus in Upper Silesia. His report blamed the government and social conditions for the outbreak. He stated "Medicine is a social science, and politics is nothing else but medicine on a large scale" [3]. He adored the first chair of pathological Anatomy at the University of Wurzberg in 1849. The campus of Charite is now named Campus Virchow Klinikum . In 1861, he was elected a foreign member of the Royal Swedish Academy of Science. In 1892, he was awarded the Copley Medal of the British Royal Society [2,4].

\section{SIGNIFICANT CONTRIBUTIONS[5,6,7,8,9]}

- Published 'Cellular Pathology' in 1858

- Carried out first systematic autopsy in 1845

- Linked the origin of cancers from otherwise normal cells (Chronic irritation theory )

- Identified Leukemia (1847)

- Described Chordoma

- Virchow`s triad - endothelial injury, stasis and hypercoagulability of blood.

- Introduced terms - Zoonosis, Chromatin, Agenesis, Parenchyma ,Osteoid, Amyloid degeneration, Spina bifida

- Described the lifecycle of Trichinella spiralis in 1859

- Encouraged use of microscopes by medical students.

- Discovered Ochronosis ( accumulation of homogentisic acid in connective tissues) in 1884

- First to analyze hair in criminal investigation in 1861

- Oppose the Pasteur`s and Koch`s germ theory of disease - considered social factors as poverty as major cause of disease.

- Virchow`s Node (metastatic cancer in lymph node in left supraclavicular fossa - Troisier's sign )

- Virchow-Robin spaces (enlarged perivascular spaces )

- Virchow`s line (line from root of nose to lamda)

- Virchow`s Law (During craniosynostosis, skull growth is restricted to a plane perpendicular to the affected , prematurely fused suture and is enhanced in a plan parallel to it)

- Virchow`s cell (macrophages in Hansen`s disease)

Virchow died from heart failure at the age of 60 in Berlin, on $5^{\text {th }}$ September 1902. The Rudolf Virchow Award is given by the society for medical Anthropology for research achievements in medical anthropology . Rudolf Virchow lecture, an annual public lecture is organized by the Romisch-Germanisches 
Zentral museum Mainz, for eminent scientists in the field of palacolithic archeology . The Rudolf Virchow center, a biomedical research center in the University of Wurzberg was established in January 2002.

\section{References}

[1]. The Columbia Encylopedia $6^{\text {th }}$ Ed 2015. http://www.encyclopedia.com Accessed $29^{\text {th }}$ January 2016.

[2]. Boak AE. Rudolf Virchow -Anthropologist and Archeologist . The Scientific Monthly 1921;13(1)40-45.

[3]. Taylor R, Rieger A .Medicine as a social science : Rudolf Virchow on the typhus epidemic in upper filetia . International Journal of Health services 1985;15(4):547-559.

[4]. Brown TM, Elizabeth F. Rudolf Carl Virchow. American Journal of Public Health 2006;96(12):2014-2015.

[5]. Wagner RS. Anecdotal, historical and critical commentaries on genetics basis of somatic ecology. Genetics 1999; 151(3):917-920.

[6]. Degos L. John Hughes Bennett, Rudolph Virchow ....and Alfred Donne : the first description of leukemia . The Haematology Journal 2001; 2(1): 1

[7]. Bagot CN, Arya R. Virchow and his triad : a question of attribution . British Journal of Haematology 2008;143(2) : 180-189.

[8]. Jilford M . Rudolf Virchow : Cellular Pathologist . Laboratory Medicine 2010; 41(5) : 311-312.

[9]. http://en.wikipedia.org/wiki/Rudolf_Virchow, accessed $29^{\text {th }}$ January 2016. 